\title{
Evaluation of heat treated clay for potential use in intervention mortars
}

\author{
Meral Budak ${ }^{a}$, Sedat Akkurt ${ }^{\mathrm{a}, *}$, Hasan Böke $^{\mathrm{b}}$ \\ a Department of Mechanical Engineering, Izmir Institute of Technology, 35430, Urla-Izmir, Turkey \\ ${ }^{\mathrm{b}}$ Department of Architectural Restoration, Izmir Institute of Technology, 35430, Urla-Izmir, Turkey
}

\section{A R T I C L E I N F O}

\section{Article history:}

Received 25 September 2008

Received in revised form 16 November 2009

Accepted 17 November 2009

Available online 26 November 2009

\section{Keywords:}

Historical mortar

Characterization

Pozzolanic activity

Aggregate

\begin{abstract}
A B S T R A C T
In this study, raw material compositions, basic physical, mineralogical, microstructural and hydraulic properties of lime mortars used in two selected historic buildings were determined by XRD, SEM-EDS and TGA analyses. The results showed that the mortars were hydraulic due to the use of pozzolanic aggregates. Taking into account the hydraulic characteristics of mortars due to the use of pozzolanic aggregates, the possibility of obtaining hydraulic mortars by using pozzolanic aggregates produced from heated commercial clays was investigated. For this purpose, four clay samples used in the ceramic industry in Turkey were heated at varying temperatures of $400,450,500,550,600,800$, and $1200^{\circ} \mathrm{C}$ with a heating rate of $10^{\circ} \mathrm{C} / \mathrm{min}$. Pozzolanic properties of heated clay samples were determined. The results showed that commercial clays studied are well suited for use as pozzolanic aggregates when they are heated between 500 and $700{ }^{\circ} \mathrm{C}$. This is also confirmed by testing the compressive strengths of the three month aged laboratory-produced mortars that contained thermally treated clay $\left(\right.$ at $600{ }^{\circ} \mathrm{C}$ ) as pozzolanic aggregates. Compressive strength of this mortar was around $5 \mathrm{MPa}$ which is satisfactorily high.
\end{abstract}

(C) 2009 Elsevier B.V. All rights reserved.

\section{Introduction}

Mortars, produced by mixing binder and aggregates, have been used for bedding, jointing and rendering brickwork and stonework. The oldest mortar used for building was mud, and is still used in many countries throughout the world. In ancient Egypt, mud mortar was used with sun-dried bricks and later gypsum was used as binder in the brick vaults of monumental buildings (Davey, 1961). Lime mortars were commonly used in buildings from Greek times through the beginning of the 19th century (Vendrell-Saz et al., 1996). They are primarily composed of lime as binder and aggregate as filler material.

Lime is produced by calcination of limestone to convert carbonate into oxide (quicklime). This oxide when mixed with water transforms into the hydroxide of calcium. Aggregates generally comprise a large part of the volume of lime mortar and the characteristics of the aggregates chosen are critical for the performance of the mortar. Aggregates can be classified as inert aggregates and pozzolanic aggregates. Inert aggregates do not react with lime. However, the pozzolanic aggregates are active and react with lime in the presence of water (Davey, 1961). Pozzolanic aggregates may be divided into two separate groups; those consisting of natural pozzolans and those of artificial pozzolans (Lea, 1940; Cowper, 2000; Moropoulou et al., 2004).

\footnotetext{
* Corresponding author. Tel.: +90 232750 6705; fax: +90 2327506701 . E-mail address: sedatakkurt@iyte.edu.tr (S. Akkurt).
}

Natural pozzolans include such materials as some diatomaceous earths, opaline, cherts, shales, tuffs and volcanic ashes. The artificial pozzolans are mainly products obtained by the treatment of natural materials such as clays, shales and fly-ash (Lea, 1940). The most common artificial pozzolan is obtained by the heat treatment of clay. The characteristics of clay are therefore important to have an idea about its pozzolanic character. The loss of combined water in the structure of clay leads to destruction of the crystal structure after thermal treatment. The silica and alumina transform into an amorphous state (Baronia and Binda, 1997; Charola and Henriques, 1999). When they are mixed with lime and water, they can produce pozzolanic reactions. Therefore, the determination of the temperature range where the clay turns into an unstable amorphous state is very important.

Determination of lime mortar characteristics for conservation works of historic buildings became an important task in the second half of the 20th century due to the extensive damage of cement mortars used in historic buildings (Rodriguez-Navarro et al., 1998). Historic buildings should be conserved by original materials and intervention materials used in the restoration must be compatible with original ones. Hence, the characterization of building materials plays an important role in restoration works of historic buildings.

The aim of this work is the characterization of aggregates that were used in historic lime mortars collected from Çukur Hamam and Hacet Mescidi, and according to the results, to determine the characteristic of clay samples which will be used as pozzolanic aggregate for the production of intervention mortars that are compatible with the original ones. 


\section{Experimental procedure}

\subsection{Characterization of lime mortars and their aggregates}

In this study, lime mortars were collected from two buildings which were both constructed in 14th century. These buildings are known as Çukur Hamam (Ç) and Hacet Mescidi (H) and are located in the city of Manisa in western Turkey (Fig. 1). Table 1 shows codes and locations of all samples. Basic physical properties, microstructural features, mineralogical and chemical compositions of the mortars were determined by XRD and SEM-EDS. TGA analysis was done in a separate study by one of the authors (Budak, 2005).

Bulk density and porosity of the mortars were determined by measuring the dry, water saturated under vacuum, and hydrostatic weights of samples (RILEM, 1980). Lime and aggregate ratios of mortars were determined by dissolving the carbonated lime in mortars with dilute hydrochloric $(\mathrm{HCl})$ acid (Jedrzejevska, 1981; Middendorf and Knöfel, 1990).

Pozzolanic activities of the aggregates (less than $53 \mu \mathrm{m}$ size) were determined by measuring the differences in electrical conductivities $(\mathrm{mS} / \mathrm{cm})$ before and after addition of the samples into saturated calcium hydroxide solution (Luxan et al., 1989). The mineralogical compositions, microstructures and chemical compositions of aggregates were determined by XRD and SEM-EDS analyses. Philips X-Pert Pro X-Ray Diffractometer ( $\mathrm{CuK} \alpha$ radiation) in the range of $2-70^{\circ}$ and Philips XL 30S FEG Scanning Electron
Table 1

Identification codes of collected samples and their description.

\begin{tabular}{ll}
\hline Identification codes & Description \\
\hline Ç-M-BB1 & Brick masonry mortar (dome starting point) \\
Ç-M-BB2 & Brick masonry mortar (dome) \\
Ç-M-SS & Stone masonry mortar (entrance door) \\
Ç-M-BB3 & Brick masonry mortar (dome) \\
H-M-BB & Brick masonry mortar (dome) \\
H-M-SS & Stone masonry mortar (wall) \\
\hline
\end{tabular}

C: Çukur Haman (bath), H: Hacet Mescidi (Mosque), BB: mortar samples from two layers of brick, SS: mortar sample from two layers of stones and M: mortar.

Table 2

The commercial codes of clay samples

\begin{tabular}{lllll}
\hline Codes & K-31 & K-103 & K-244 & K-261 \\
\hline Source & Tamsa Seramik A.Ș & Yüksel Seramik A.Ş & Kalemaden A.Ș & Kalemaden A.Ş
\end{tabular}

Microscope (SEM) coupled with X-Ray Energy Dispersive System (EDS) were used in the analyses (Table 2).

\subsection{Heat treatment of commercial clays}

In this study, the possibilities of producing pozzolanic aggregates by calcination of some commercial clays were investigated. For this

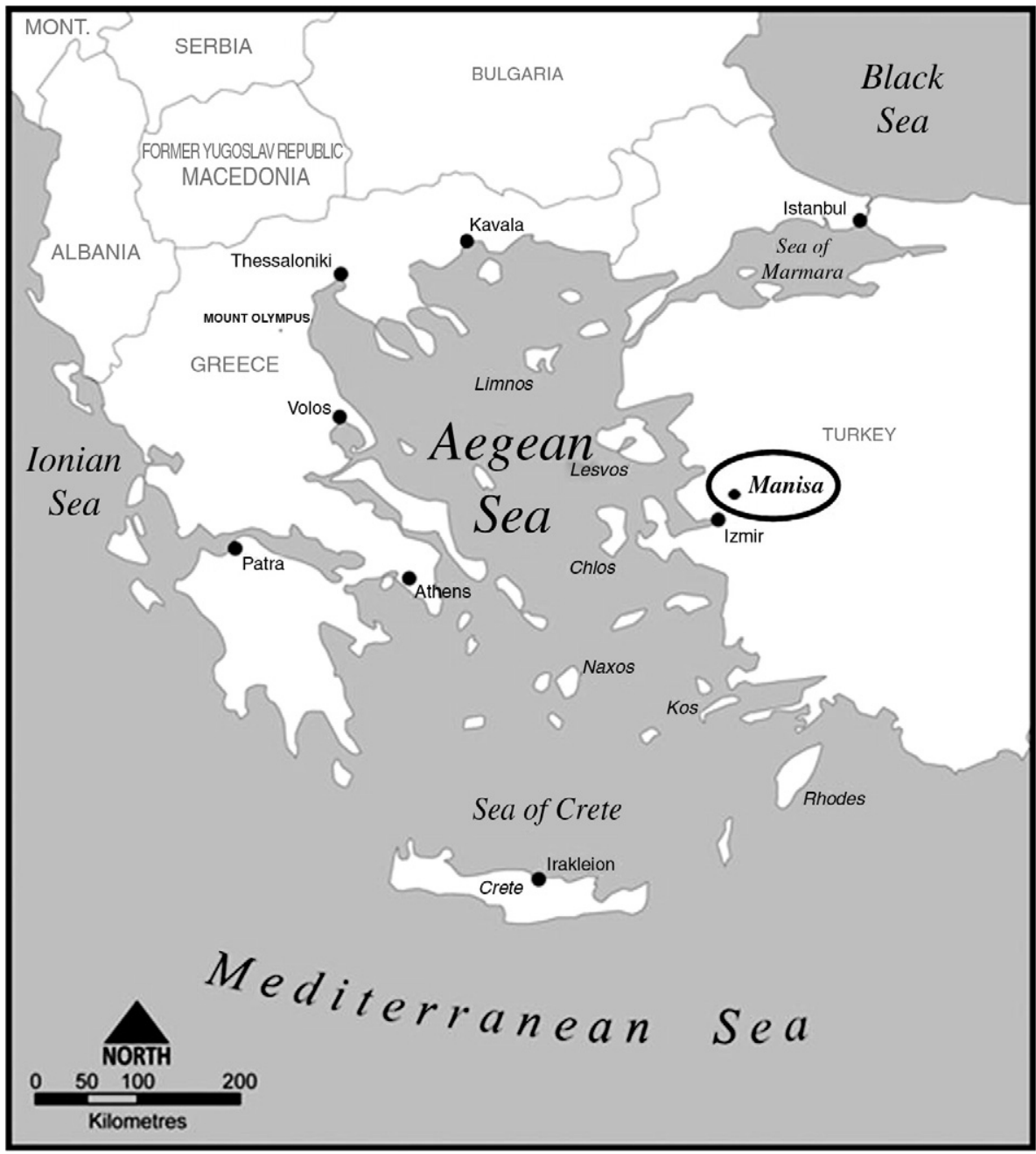

Fig. 1. Map of Turkey showing the location of Manisa. 
Table 3

The mixing ratios of binders, aggregates and pozzolans used in preparation of mortar.

\begin{tabular}{lllll}
\hline $\begin{array}{l}\text { Mortar } \\
\text { no. }\end{array}$ & $\begin{array}{l}\text { Binder } \\
\text { aggregate } \\
\text { ratio }(\mathrm{g})\end{array}$ & \multicolumn{3}{l}{ Pozzolan/aggregate ratio $(\mathrm{g})$} \\
\cline { 3 - 5 } & $1 / 3$ & $\begin{array}{l}\mathrm{K}-244 \\
\left(25{ }^{\circ} \mathrm{C}\right)\end{array}$ & $\begin{array}{l}\mathrm{K}-244 \\
\left(600{ }^{\circ} \mathrm{C}\right)\end{array}$ & $\begin{array}{l}\mathrm{K}-244 \\
\left(1000{ }^{\circ} \mathrm{C}\right)\end{array}$ \\
\hline 1 & $1 / 3$ & $1 / 2$ & $1 / 2$ & \\
2 & $1 / 3$ & & & $1 / 2$ \\
3 & & & & \\
\hline
\end{tabular}

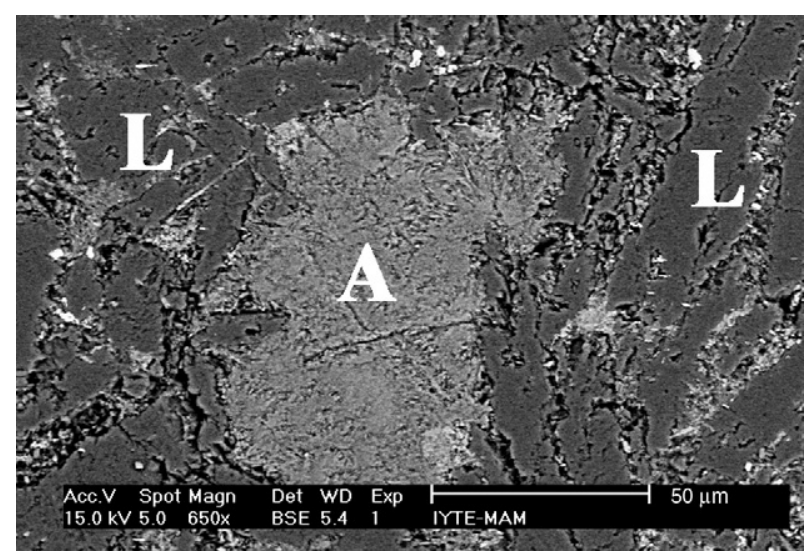

Fig. 2. BSE image showing good adhesion between aggregates(A) and lime(L).

purpose, some commercial clays used in the ceramics industry in Turkey were obtained (Table 3). The chemical compositions of clay samples were determined by SEM-EDS analysis. Clay samples were heated at varying temperatures of $400,450,500,550,600,800$, and $1200{ }^{\circ} \mathrm{C}$ with a heating rate of $10{ }^{\circ} \mathrm{C} / \mathrm{min}$. Pozzolanic properties of heated samples (less than $53 \mu \mathrm{m}$ size) were determined by measuring the differences in electrical conductivities $(\mathrm{mS} / \mathrm{cm})$ before and after addition of the samples into saturated calcium hydroxide solution (Jedrzejevska, 1981).

\subsection{Preparations of intervention mortars and their uniaxial compressive strengths}

$\mathrm{K}-244$ sample was used as pozzolanic aggregate in the preparation of intervention mortars. The binder (lime) to standard sand aggregate ratios were 1:3. Pozzolan additions were made to these mixes in such proportions to obtain pozzolan/aggregate ratios of $1 / 2$ (Table 3 ).

Mortar mixtures were prepared by following the procedure outlined in ASTM standard (ASTM C109, 2005). The commercial hydrated lime used in preparation of mortar was supplied by Öztüre Kimtaş A.Ş Izmir. The graded standard aggregates were supplied from Çimentaş A.Ş Izmir. Mortar mixtures were prepared by using a Kitchenaid ${ }^{\circledR}$ mini mixer (5lt). After the mixing procedure the samples were cast in cylindrical molds made from commercially available PVC pipes ( $R=5 \mathrm{~cm}, h=5 \mathrm{~cm}$ ). ASTM C593 standard was used for storage of the mortar mixtures (ASTM C593, 2005). After 3 months of storage at $23 \pm 2{ }^{\circ} \mathrm{C}$ at 95 to $100 \%$ relative humidity, their uniaxial compressive strength values (UCS) were determined by using a Shimadzu AG-I Mechanical Test Instrument.

\section{Results and discussion}

\subsection{Properties of lime mortars and aggregates}

Density values of stone and brick masonry mortar samples collected from Çukur Hamam and Hacet Mescidi were 1.8 and $1.9 \mathrm{~g} / \mathrm{cm}^{3}$, and porosity values were 34 and $29 \%$ by volume, respectively. Density and porosity values of the mortar samples were in a similar range with some

a

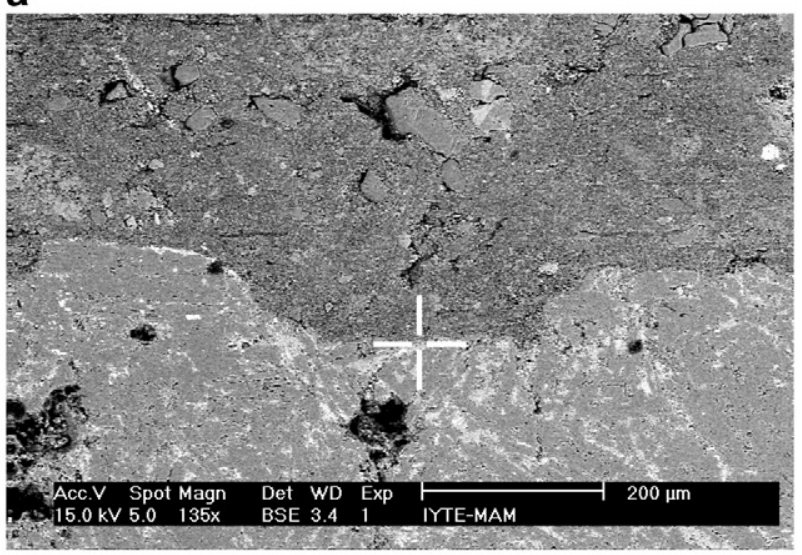

b

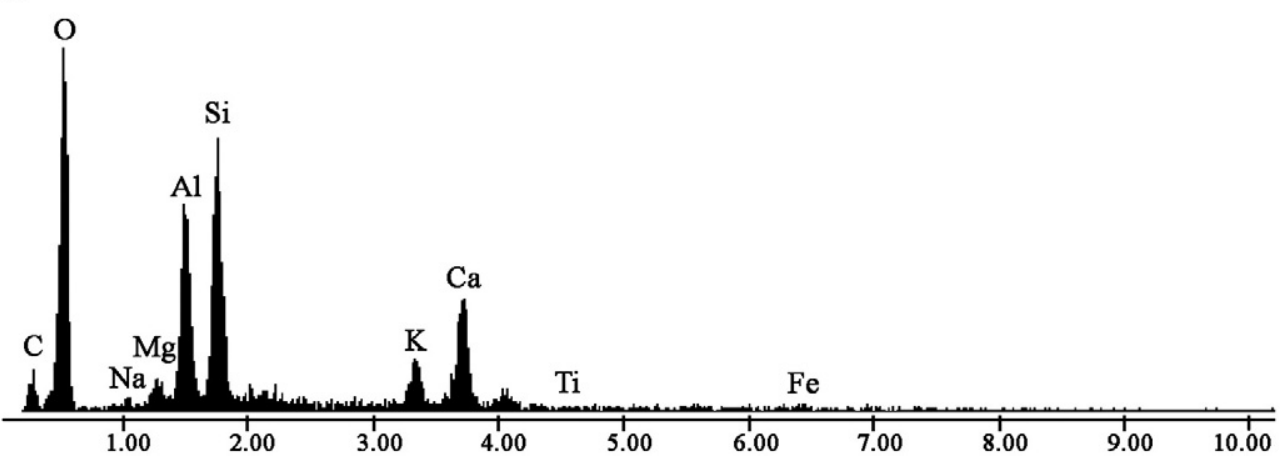

Fig. 3. BSE image (a) and EDS spectrum (b) of the interface between lime and the aggregate surface. 


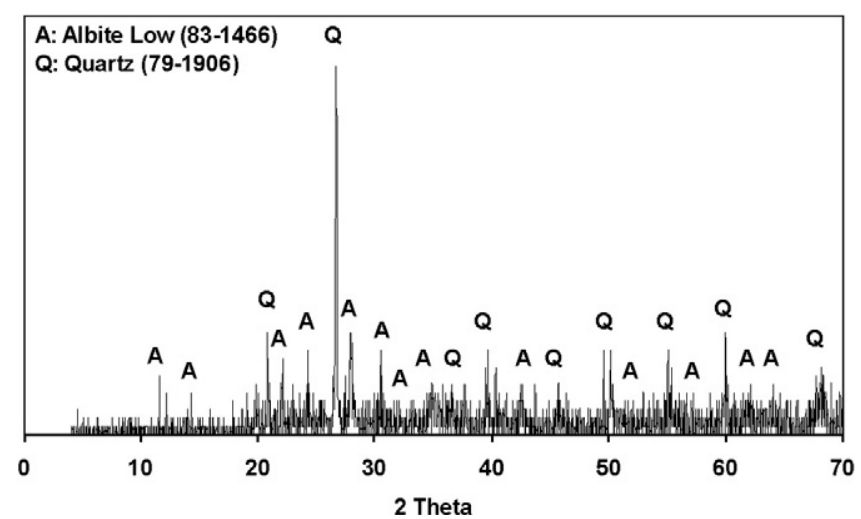

Fig. 4. XRD pattern of the fine aggregates used in brick masonry mortar of C-M-BB2.

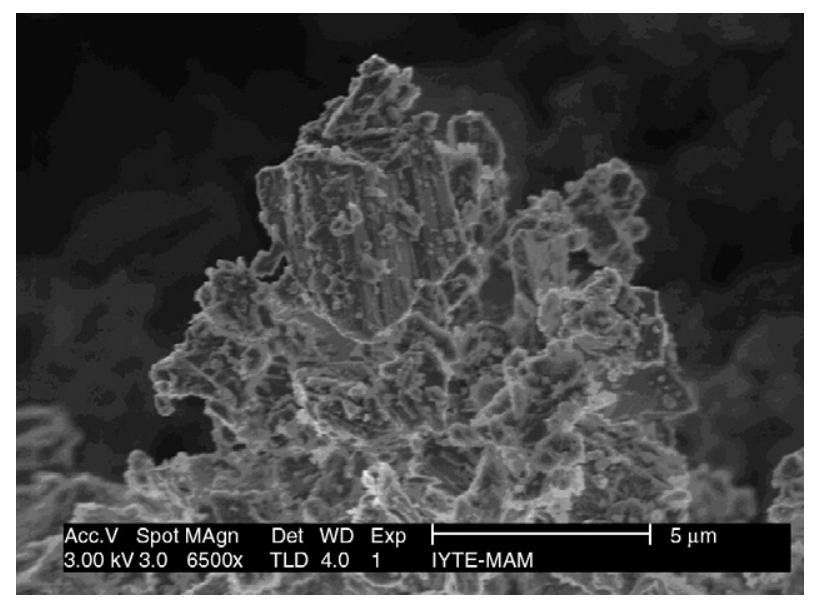

Fig. 5. SE (secondary electron) image of fine aggregates.

other historic lime mortars from different periods of time (Moropoulou et al., 2004; Böke et al., 2006).

Lime/aggregate ratios of the mortars samples ranged from $1: 2$ to $1: 4$. Stone masonry mortars of the structures presented high ratios of lime when compared with the brick masonry mortars. Aggregate particle sizes that are greater than $1180 \mu \mathrm{m}$ composed the largest portion of the total aggregates. These values were in similar ranges to mortars and plasters used in some historic structures (Moropoulou et al., 2000; Bakolas et al., 1998).

The mortars were stiff, hard and compact due to strong cohesion between aggregates and lime (Fig. 2). The aggregates were mostly semi-rounded and porous permitting strong adherence to the lime.
Aggregate-lime interfaces were composed largely of calcium, silicon and aluminum (Fig. 3). This may indicate the formation of hydraulic compounds produced by the reaction of pozzolanic aggregates with lime.

The hydraulicity of the mortars was evaluated by thermo gravimetric analyses (TGA) in a previous study by the authors. These analyses indicated that the weight loss between $200{ }^{\circ} \mathrm{C}$ and $600{ }^{\circ} \mathrm{C}$ was nearly $2.2 \%$ and weight loss over $600{ }^{\circ} \mathrm{C}$ was $12.9 \%$ (Budak, 2005). It has been estimated that if the $\mathrm{CO}_{2}$ /water ratio is between 1 and 10 in a mortar, it can be regarded as a hydraulic mortar. The $\mathrm{CO}_{2}$ /water ratios for mortars were less than 10; hence they were classified as hydraulic mortars (Moropoulou et al., 2000).

\subsection{Properties of aggregates used in mortars}

The XRD analyses of fine aggregates of mortar samples collected from Çukur Hamam and Hacet Mescidi showed that they were all composed of quartz and some albite (Fig. 4). A broad band indicating the presence of amorphous materials (Sujeong et al., 1999) could be observed between 20 and $30^{\circ}$ in XRD patterns (Fig. 4). Therefore, it can be said that there are amorphous materials in the structure of fine aggregates.

Semi quantitative SEM-EDS analysis revealed that the main component in fine aggregates was silica $\left(\mathrm{SiO}_{2}\right)$, which varied in the range of $73-85 \%$. The second component of fine aggregates was alumina $\left(\mathrm{Al}_{2} \mathrm{O}_{3}\right)$ that varied in the range of $6-10 \%$, and the third important component was iron oxide $\left(\mathrm{Fe}_{2} \mathrm{O}_{3}\right)$ which varied in the range of $1-3 \%$ (Budak, 2005).

The crystals of fine aggregates had sharp edges (Fig. 5) that caused a high surface area, which was effective for pozzolanic reaction kinetics between lime and fine aggregate. Fine aggregates adhered well to mortar matrices via pozzolanic reaction products, which improve the mechanical strength of mortar. Such mortars are known as hydraulic mortars which maintain strength under water.

Pozzolanic activities of the aggregates $(<53 \mu \mathrm{m})$ were obtained in the range of $1.71-7.23 \mathrm{mS} / \mathrm{cm}$ (Fig. 6). According to Luxan's classification of pozzolanicity (Luxan et al., 1989), the changes in electrical conductivity of calcium hydroxide solution before and after addition of pozzolanic material are classified as; good pozzolan when more than $1.2 \mathrm{mS} / \mathrm{cm}$, variably pozzolan when $1.2-0.4 \mathrm{mS} / \mathrm{cm}$ and non-pozzolanic when less than $0.4 \mathrm{mS} / \mathrm{cm}$. Measurement results in this study concluded that all aggregates could be classified as good pozzolans.

According to the results of the XRD, SEM-EDS and pozzolanic activity analyses, the fine aggregates can be characterized as pozzolanic aggregates formed from quartz and albite and amorphous materials, containing high amounts of silica and alumina with a geometry of sharp

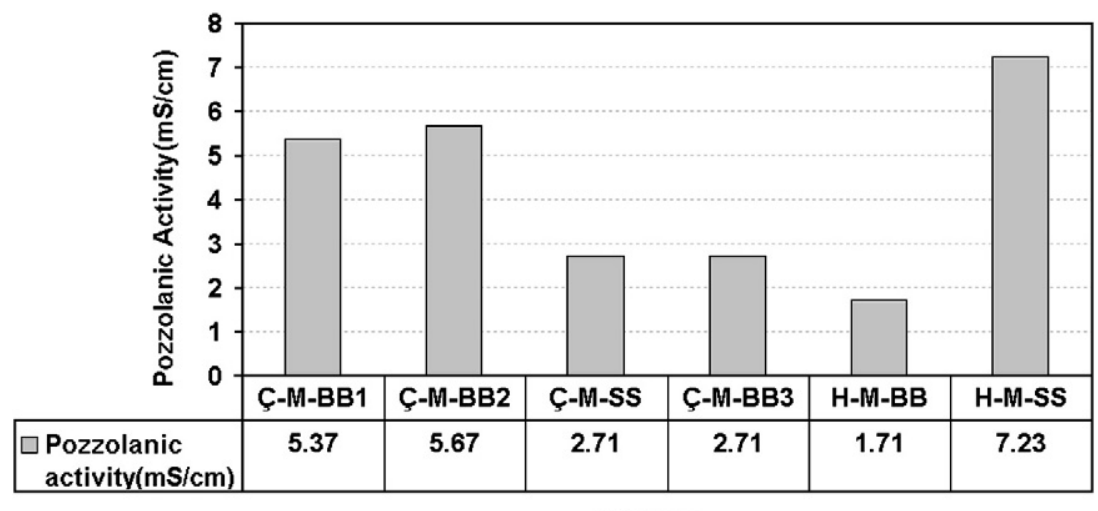

Samples

Fig. 6. Pozzolanic activity values of fine aggregates $(<53 \mu \mathrm{m})$. 
Table 4

Chemical composition of clay samples (EDS).

\begin{tabular}{lrrrr}
\hline Oxides (\%) & $\mathrm{K}-31$ & $\mathrm{~K}-103$ & $\mathrm{~K}-244$ & $\mathrm{~K}-261$ \\
\hline $\mathrm{Na}_{2} \mathrm{O}$ & 0.9 & 0.9 & 1.1 & 1.2 \\
$\mathrm{MgO}$ & 1.2 & 1.6 & 1.6 & 1.4 \\
$\mathrm{Al}_{2} \mathrm{O}_{3}$ & 41.4 & 33.3 & 33.1 & 40.8 \\
$\mathrm{SiO}_{2}$ & 52.6 & 56.5 & 58.7 & 53.4 \\
$\mathrm{~K}_{2} \mathrm{O}$ & 2.4 & 2.6 & 2.4 & 0.4 \\
$\mathrm{CaO}$ & 0.1 & 0.4 & 0.4 & 0.2 \\
$\mathrm{TiO}_{2}$ & 0.3 & 1.3 & 1.0 & 1.0 \\
$\mathrm{Fe}_{2} \mathrm{O}_{3}$ & 1.1 & 3.4 & 1.6 & 1.6 \\
\hline
\end{tabular}

edges. The aggregate that will be used in production of intervention mortar should have similar properties to the fine aggregates.

\subsection{Properties of heat treated clays}

SEM-EDS analysis showed that the clay samples had oxide contents in the range of $52-58 \%$ for $\mathrm{SiO}_{2}, 33-41 \%$ for $\mathrm{Al}_{2} \mathrm{O}_{3}, 0.9-1.2 \%$ for $\mathrm{Na}_{2} \mathrm{O}$ and $0.4-2.6 \%$ for $\mathrm{K}_{2} \mathrm{O}$ (Table 4 ). Their pozzolanic activity (PA) values at different temperatures are given in Fig. 7 (Budak et al., 2003). The results show that most clay samples were not sufficiently pozzolanic before heat treatment. The maximum PA values were obtained for the K-103 sample while the lowest PA was shown by the K-31 sample before heat treatment. High pozzolanic activity of K-103 sample can be attributed to natural pozzolans in the structure of this sample. The pozzolanic activity measurement at different temperatures showed that the maximum pozzolanic activity values for all samples were obtained in the range of $550-600{ }^{\circ} \mathrm{C}$. This result was expected because the clay crystal structures were disrupted and an amorphous material was produced by heating at this temperature range (Sujeong et al., 1999). Pozzolanic activity values of samples decreased when this temperature range was exceeded (e.g. when $T>600-800{ }^{\circ} \mathrm{C}$ ). This fall of PA can be attributed to decreasing surface area due to heat treatment. The fall of pozzolanic activity values in the range of $800-1200{ }^{\circ} \mathrm{C}$ is the result of both surface area decrease and the decomposition of amorphous structures, and formation of new minerals like mullite.

\subsection{Compressive strengths of lime mortars produced from heated clays}

Taking into account the pozzolanicity tests, K-244 sample was used as pozzolanic aggregates in the preparation of intervention mortars. Intervention mortars were aged at $23 \pm 2{ }^{\circ} \mathrm{C}$ in 95 to $100 \%$ relative humidity for 3 months. After 3 months, their uniaxial compressive strength values (UCS) were determined by using a Shimadzu AG-I Mechanical Test Instrument.

Compressive strength results (Table 5 ) showed that the samples containing thermally treated clay $\left(600^{\circ} \mathrm{C}\right)$ gained higher compressive

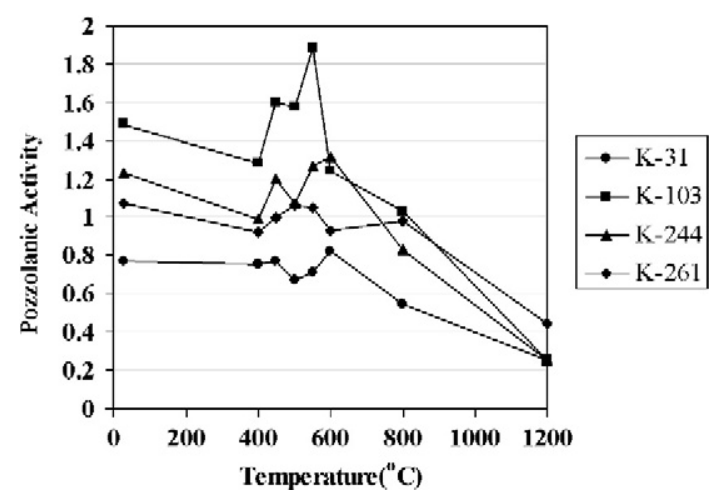

Fig. 7. Pozzolanic activity test results of clay samples heated at temperatures between 200 and $1000{ }^{\circ} \mathrm{C}$.
Table 5

Compressive strength test results of mortar samples prepared by using K-244 clay sample after 3 months of aging.

\begin{tabular}{llllll}
\hline Mortar no. & Pozzolana & \multicolumn{2}{l}{$\begin{array}{l}\text { Compressive strengths of } \\
\text { the three samples } \\
\text { (MPa) }\end{array}$} & (3 months) \\
\hline 1 & K244 (unheated) & 0.82 & 0.78 & - & 0.8 \\
2 & $\mathrm{~K} 244\left(600^{\circ} \mathrm{C}\right)$ & 4.46 & 4.94 & 5.75 & 5.05 \\
3 & $\mathrm{~K} 244\left(1000^{\circ} \mathrm{C}\right)$ & 1.84 & 2.43 & - & 2.14 \\
\hline
\end{tabular}

strength values compared to other clay samples that were either unheated or excessively heated at $1000^{\circ} \mathrm{C}$. This result shows the consistency of the pozzolanicity tests with the compressive strength tests.

\section{Conclusions}

In this study, mortar samples collected from Manisa Çukur Hamam and Hacet Mescidi were characterized and were found to be hydraulic due to the use of natural pozzolanic aggregates. A series of four different commercial clay samples were selected for study to find out whether they would be applicable as a pozzolanic additive in an intervention mortar after a thermal treatment. The results showed that commercial clays can be used as good pozzolanic aggregates if they are heated between 500 and $700{ }^{\circ} \mathrm{C}$.

\section{Acknowledgments}

The authors thank the researchers of the Centre for Materials Research at the Izmir Institute of Technology for XRD and SEM-EDS analyses during the experimental stage of this study.

\section{References}

ASTM C109, 2005. American National Standard, Standard Test Method for Compressive Strength of Hydraulic Cement Mortars (Using 2-in or 50-mm Cube Specimens), pp. 64-70.

ASTM C593, 2005. American National Standard, Standard for Specification for Fly Ash and Other Pozzolans for Use with Lime, pp. 369-374.

Bakolas, A., Biscontin, G., Moropoulou, A., Zendri, E., 1998. Characterization of structural byzantine mortars by thermogravimetric analysis. Thermochimica Acta 321 151-160.

Baronia, G., Binda, L., 1997. Study of pozzolanicity of some bricks and clays Construction and Building Materials 11-1, 41-46.

Budak M., 2005. Characterization of selected beylikler period mortars and processing of new intervention mortars for restoration purposes. Masters Thesis, Izmir Institute of Technology, Izmir, Turkey.

Budak, M., Sütçü, M., Akkurt, S., Boke, H., 2003. Koruma amaçlı horasan harc hazırlanmasında kullanılacak ticari killerin kullanım koșullarının araștırılması. XI Ulusal Kil Sempozyumu, 3-6 Eylul, Izmir, Turkey.

Böke, H., Akkurt, S., İpekoğlu, B., Uğurlu, E., 2006. Characteristics of brick used as aggregate in historic brick-lime mortars and plasters. Cement and Concrete Research 36, 1115-1122.

Charola, E.A., Henriques, F.M.A., 1999. Hydraulicity in lime mortars revisited. Proceedings of RILEM TC-167COM International Workshop, Historic mortars: characteristics and tests. RILEM, Paisley. pp. 97-106.

Cowper, A.D., 2000. Lime and lime mortars. Donhead Publishing Ltd, Dorset.

Davey, N., 1961. Limes and cements, and mortar and concrete, in history of building materials. Phoenix House, London. pp. 97-127.

Jedrzejevska, H., 1981. Ancient mortars as criterion in analysis of old architecture. Proceedings of Symposium on Mortars, Cements, and Grouts Used in the Conservation of Historic Buildings, Rome, pp. 311-329.

Lea, F.M., 1940. Investigations on pozzolans. Building Research, Technical Paper 27. $1-63$.

Luxan, M.P., Madruga, F., Saaved, J., 1989. Rapid evaluation of pozzolanic activity of natural products by conductivity measurement. Cement and Concrete Research 19 , 63-68.

Middendorf, D.R., Knöfel, D., 1990. Use of old and modern analytical methods for the determination of ancient mortars in northern Germany, Proceedings of the $3^{\mathrm{rc}}$ Expert Meeting, Hamburg. NATO-CCMS Pilot Study on the Conservation of Historic Brick Structures, Berlin, Germany. pp. 75-92.

Moropoulou, A., Bakolas, A., Bisbikou, K., 2000. Investigation of the technology of historic mortars. Journal of Cultural Heritage 1, 45-58 
Moropoulou, A., Bakolas, A., Aggelakopoulou, E., 2004. Evaluation of pozzolanic activity of natural and artificial pozzolans by thermal analysis. Thermochimica Acta 420, 135-140.

RILEM, 1980. Tests defining the structure. Materials and Construction 13, 73.

Rodriguez-Navarro, C., Hansen, E., Ginell, W.S., 1998. Calcium hydroxide crystal evaluation upon aging of lime putty. Journal of American Ceramic Society 81, 3032-3034.
Sujeong, L., Kim, Y.L., Moon, H., 1999. Phase transformations sequence from kaolinite to mullite investigated by an energy-filtering transmission electron microscope. Journal of the American Ceramic Society 82, 2841-2848.

Vendrell-Saz, M., Alarcón, S., Molera, J., Garcia-Vallés, 1996. Dating ancient lime mortars by geochemical and mineralogical analysis. Archaeometry 38, 143-149. 